\title{
Geological setting, mining and reduction of mercury vapor contamination in the gold-silver district of Vetas-Calofornia (Santander, Colombia)
}

1 Corporación Autónoma Regional Para la Defensa de la Meseta de Bucaramanga, Carrera 23 N37-63, Bucaramanga, Colombia, E-mail:prs1@cdmb.gov.co

2 Formely with Corporación Autónoma Regional Para la Defensa de la Meseta de Bucaramanga, Carrera 23 N³7-63, Bucaramanga, Colombia.

3 Formerly with Federal Institute for Geosciences and Natural Resources, Stilleweg 2, 30655 Hannover, Germany;

E-mail: cristof.bernardy@omya.com

Bucaramanga, with a population of about one million, is the capital of the Department of Santander (Colombia), and has the Río Suratá as its main source of drinking water. In the upper reaches of the river, small-scale gold mining has been going on for many centuries (Vetas-California mining district). Geologically, the Vetas-California mining district is part of the Santander Massif, which is composed of pre-Devonian metamorphic rocks and Mesozoic igneous rocks. The mineralisation is restricted to structurally controlled veins and is often associated with hydrothermal alteration. There is also disseminated mineralisation, but presently only the vein-type is mined. The processing residues are discharged into the nearby watercourses, contaminating the waters of the Suratá river basin. As part of a joint Colombian-German technical cooperation project, with the purpose of controlling the negative environmental effects of gold mining pollution, an integrated distillation system for the recovery of mercury has been designed and tested.

\section{Introduction}

Bucaramanga, with a population of about one million, is the capital of the Department of Santander (Colombia) and has the Suratá river basin as its main source of drinking water. In the upper reaches of the river, small-scale gold mining operations have been conducted for many centuries. Mercury and cyanide are used to extract the gold. The residues are usually discharged into nearby waterways (Figure 1).

In 1997, an International Technical Cooperation Agreement was implemented between Colombia and Germany to develop the "Reduction of environmental contamination by small-scale mining operations in the Suratá river basin" project (known as the Río Suratá Project). On behalf of Colombia, the project involves Compañía de Acueducto Metropolitano de Bucaramanga (CAMB, Metropolitan Aqueduct Company of Bucaramanga), the Gobernación de Santander (Government of Santander) and the Corporación Autónoma Regional para la Defensa de la Meseta de Bucaramanga (CDMB, Regional Autonomous Corporation for the Protection of the Bucaramanga Plateau). The latter institution coordinates the project activi-

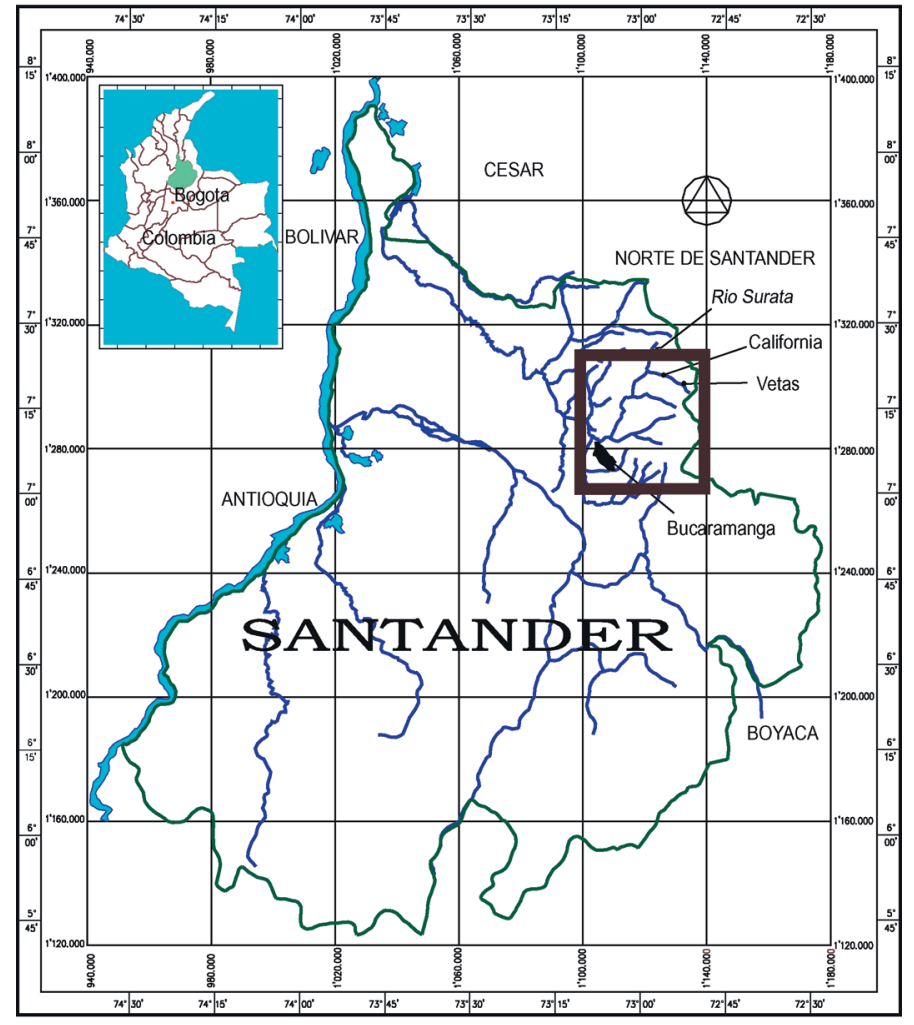

Figure 1 Location map of the project area.

ties. The German government is represented in the project by the Bundesanstalt für Geowissenschaften und Rohstoffe (BGR, Federal Institute for Geosciences and Natural Resources).

The project aims to reduce the environmental impact of the production processes from small-scale vein-gold mining in the VetasCalifornia district (Santander, Colombia), especially at mining operations using amalgam and cyanide treatment processes, which result in serious environmental pollution.

To achieve its goals, the Río Suratá Project chose a strategy of "Reducing the environmental impact by improving the existing ore treatment processes" to encourage mining operations which are both environmentally beneficial and economically sustainable. 


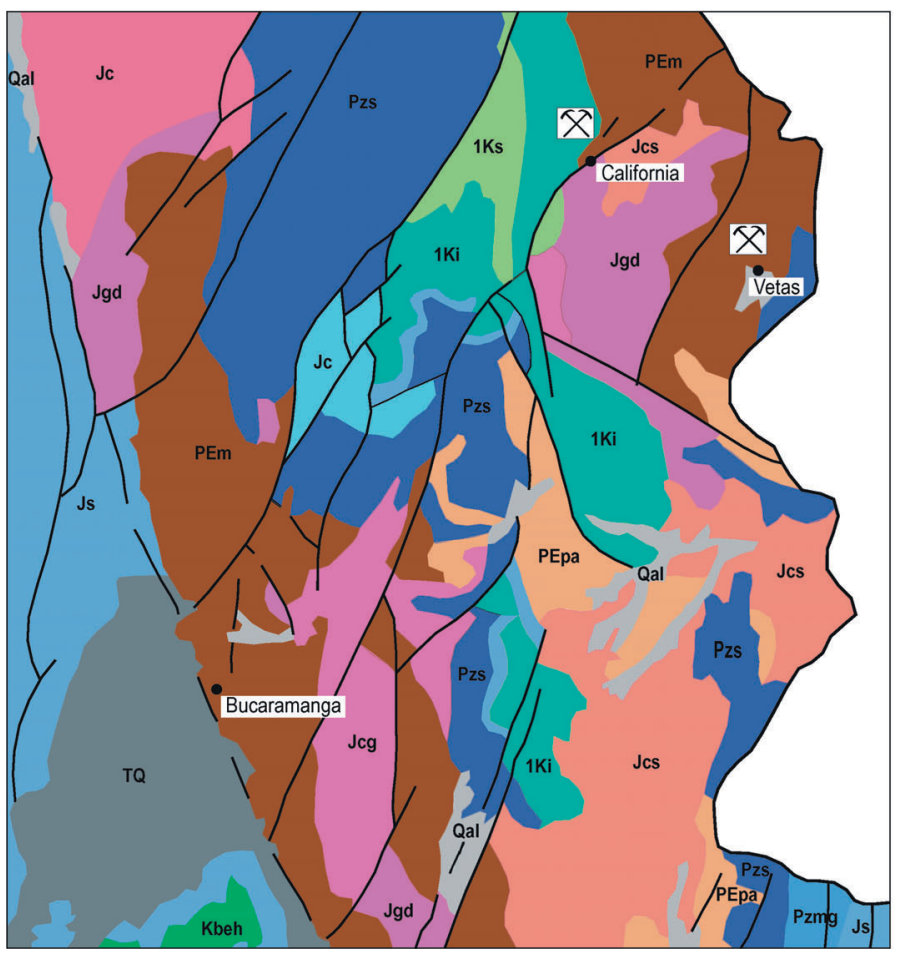

Figure 2 Geological sketch map of the work area (modified after INGEOMINAS, 1999).

\section{Regional and local geology}

\section{Regional geology}

According to Mendoza and Jaramillo (1979), the Vetas-California mining district is part of the Santander Massif, which consists of a complex of pre-Devonian metamorphic rocks and Mesozoic igneous rocks (Figure 2). The geology of the Santander Massif has been described by Ward et al. (1973) and includes Precambrian high-grade metamorphic rocks affected by thermodynamic regional metamorphism (amphibolite facies). These rocks were mapped by Mendoza and Jaramillo (1979) as the central gneiss belt of Bucaramanga, consisting of para-gneisses, pelitic and arenaceous schists, hornblendebearing gneiss and migmatites. Medium- to low-grade metamorphic rocks, which include micaceous schists, phyllites, meta-arenites, quartzites and marbles, can be correlated with the Silgará Formation of the Cambro-Ordovician age. The central part of the Santander Massif contains medium- to high-grade metamorphic orthogneiss of granitic to tonalitic composition, and low-grade metamorphic rocks such as slates, meta-siltstones, graphitic phyllites, meta-arenites and marble, which belong to the Floresta Formation and which cover part of the orthogneiss and Silgará Formation. Their age is considered to be mid-Devonian. Batholites and plutononic rocks of felsic to intermediate composition intruded during Triassic to Jurassic times caused the local development of migmatites.

The structural setting of the Santander Massif is dominated by complex faulting, with a major regional NNW-trending fault apparently extending as far as Santa Marta (Ward et al., 1973). Associated with this major fault are NNE- to NNW-striking local faults, and some transverse cross-faults which cut across these alignments.

\section{Geology of the Vetas district}

In the Vetas region, León et al. (1995) encountered migmatitic gneisses, which are texturally and compositionally differentiated into quartzo-feldspathic and biotite-hornblende gneisses with agmatic and ptygmatic structures, which were correlated with rocks of the central gneiss belt of Bucaramanga. Pre-Devonian orthogneisses of quartzmonzonitic, granodioritic, tonalitic and dioritic composition are

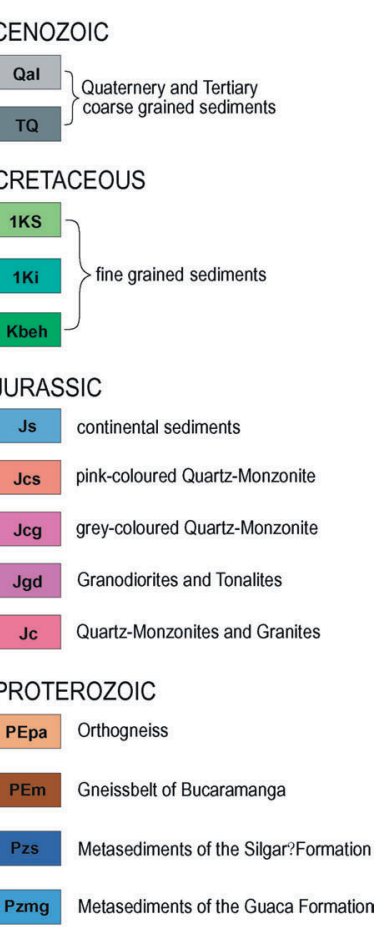

intruded in the Vetas region by granitic and granodioritic stocks of Triassic to Jurassic age, and granitoid and granodioritic dikes, the latter with variable strike directions and aplitic textures, and composed of more than $60 \%$ quartz and albitic plagioclase.

Faults and lineaments were identified as part of a major NE-trending fracture system.

\section{Geology of the California district}

After Mendoza and Jaramillo (1979), the rocks of the California area are composed of high-grade complexly deformed metamorphites (migmatites), intrusive bodies of magmatic origin and quartzdioritic and alaskitic composition, and of hypabyssal porphyritic dikes and sills of granodioritic and dacito-trachytic composition.

Structurally, Ward et al. (1973) defined a regional north-south directed foliation trend with west and northnortheast directed dips, a trend also followed by the emplacement of intrusive rock bodies. Mendoza and Jaramillo (1979) photogeologically identified NNE- directed lineaments, of which some correspond to faults which coincide with the drainage system of the California mining area.

\section{Mineralogy}

The mineralisation of the Vetas-California mining district is confined to veins which are structurally controlled and often associated with hydrothermal alteration. There is also disseminated mineralisation, but presently only veins are mined.

The mineralisation at Vetas is considered by León et al. (1995) to consist of semi-tabular orebodies of breccioid aspect, which fill high-angle fractures. The thickness of the mineralised veins varies from thin alteration bands to one metre thick, and the colour of the wall rock depends on characteristic hydrothermal vein minerals. The main strike directions of the mineralised fractures are $\mathrm{N} 15^{\circ}-35^{\circ} \mathrm{E}$, $\mathrm{N} 70^{\circ}-85^{\circ} \mathrm{E}, \mathrm{N} 60^{\circ} \mathrm{W}$ and $\mathrm{E}-\mathrm{W}$.

For the mineralisation at California, Mendoza \& Jaramillo (1979) determined two main mineralised fracture trends, one striking $\mathrm{N} 30^{\circ}-60^{\circ} \mathrm{W}$ and the other $\mathrm{N} 70^{\circ} \mathrm{W}$ to $\mathrm{E}-\mathrm{W}$. The mineralised fracture systems consist of a series of veins arranged en-echelon, with thicknesses varying between a few centimetres to more than one metre. The mineralisation is tectonically controlled by high-angle faulting, which is associated with the jointing system.

Polished specimens and thin sections of grab samples taken from active mines in Vetas and California have been studied by reflected and transmitted light microscopy and SEM by the BGR (Herb et al., 2000). According to these investigations, the Vetas mining district displays the typical features of an epithermal adularia-sericite-type mineralisation in the terminology of Heald et al. (1987) or of low sulphidity in the terminology of Hedenquist (1987). The sulphides mostly consist of intergrowths of pyrite and marcasite, and locally abundant galena, sphalerite and fahlore (fahlerz). Native gold is the major gold-bearing phase, and acanthite (Ag-sulphide) represents the major silver-bearing phase.

Gold grain sizes show a bimodal distribution, with fine-grained gold, ranging in size from $2-20 \mu \mathrm{m}$ and an average of $5 \mu \mathrm{m}$, enclosed in sulphides, and coarse-grained gold with grain sizes up to $250 \mu \mathrm{m}$, mostly hosted by quartz veins. 
The California mining district displays a spectrum of element enrichment different to that of the Vetas mining district, with significant enrichments of $\mathrm{Au}, \mathrm{Cu}, \mathrm{Te}, \mathrm{Sb}, \mathrm{W}, \mathrm{As}, \mathrm{Ag}, \mathrm{Pb}$ and $\mathrm{Zn}$.

This element spectrum is expressed in a more diverse mineralogy, consisting mostly of pyrite, but also containing locally significant amounts of various $\mathrm{Cu}$-sulphides, particularly bornite, chalcopyrite, tennantite and tetrahedrite, enargite, unknown $\mathrm{Cu}-\mathrm{Bi}$ sulphide and $\mathrm{Cu}-\mathrm{W}$-sulphide, chalcocite, and covellite. Locally, huebnerite can be abundant. In other places, galena and sphalerite may contribute to the sulphide mineralisation. Au-tellurides, Au-Agtellurides and hessite occur in significant amounts, but native gold, low in silver content, is the dominant gold-bearing phase.

The wall rock is highly altered to a mixture of alunite and quartz and local hematite. From the element spectrum and the mineralogy it can be assumed that the mineralisation of the California area represents the epithermal acid sulphate type in the terminology of Heald et al. (1987) or the high sulphidity type in the terminology of Hedenquist (1987).

Unlike the Vetas mining district, the grain sizes of native gold in the California district are unimodally distributed due to the lack of coarse-grained quartz-hosted gold. The grain sizes range from $2-30 \mu \mathrm{m}$. The native gold is closely associated with sulphides, and is either enclosed in pyrite, bornite or fahlore, or located at the grain boundaries of pyrite and fahlore.

\section{Mining}

The ore-processing methods of the mineralised zones have been classified into two kinds-a "formal" one and an "informal" one. The more advanced type of "formal" operations (type I) uses primary crushing, milling with ball mills, gravimetric concentration with concentration jigs or tables, amalgamation in barrels and cyanidisation by percolation. The second type of "formal" ore treatment process (type II) is less mechanised, and uses stamp milling, gravimetric concentration in channels, amalgamation in barrels and cyanidisation by percolation. Both ore-processing types work inefficiently, with estimated total gold losses of nearly $40 \%$. In the "informal" ore processing sector, which is usually named after its operators, the barrileros ("barrellers"), both milling and amalgamation are done in one process (barrel) and the residues are leached in small tanks with cyanide.

During the reconnaissance stage of the Río Suratá Project, between the second half of 1997 and the first half of 1998, mining production from 11 plants in Vetas and 14 in California amounted to $35-45,000$ tonnes of treated ore per year, with an output of 250 to 350 kilograms of gold.

Based on an average cyanide consumption of 25 to 30 tonnes per year, it is estimated that 1,000 to 1,200 kilograms of mercury are discharged by the mining activities every year into the tributaries of the Suratá river.

With an estimated 3,500 people involved, it is calculated that the mining industry accounts for nearly $90 \%$ of the local economy.

\section{Amalgamation process}

In the municipalities of Vetas and California, the ore treatment processes are crushing, milling, gravimetric concentration, amalgamation and cyanidisation. The amalgamation method is widely used in the region because of its simplicity, fast results and low operating costs.

Amalgamation is done batchwise in barrels, which are, together with mercury, charged either directly with ore or with gravimetric ore concentrates. The amalgam, the product of interest to the miner, is obtained after 8 to 18 hours of milling and amalgamation in the barrel.

\section{Recovery of amalgamated gold}

In the pyrometallurgic amalgam treatment process, gold is recovered by distilling the mercury at temperatures above $356^{\circ} \mathrm{C}$. Depend- ing on the mineral extraction method and ore treatment process, which may vary widely from mechanised plants to one-man pick and shovel operations, the quantities of obtained amalgam may be so small, e.g. 2 grams, that some miners burn the amalgam in the open air, using heating devices with charcoal and in some cases kitchen gas stoves.

Although treatment plants have retorts, which are heated in closed fusion furnaces to distill amalgam quantities of more than $300 \mathrm{~g}$, neither they nor the small-scale operators have adequate retorts for the distillation of amalgam quantities of 3-200 g. These small quantities are burnt in the open air, producing mercury vapours which pollute workplaces and occasionally housing areas, giving rise to serious health problems for the miners and their families in particular.

\section{Limitation to the recovery of mercury with traditional techniques}

Aware of the problematic mercury fumes, the Río Suratá Project supplied the miners in 1997 with carbon steel retorts, known from mining areas in the south of Colombia (Pasto, Departamento de Nariño), where the retorts were designed in the1980s for the "Mitigation of mercury emissions from small-scale gold mining at the Nariño/Colombia" project run by CORPONARIÑO and GTZ-Projekt-Consult GmbH. After testing the new retorts, the miners at Vetas and California encountered the following problems:

- Limited cooling capacity and contamination of the recovered mercury

- Lack of a rapid heating unit and physical instability of the retorts on open firewood or coke/coal forging stoves and fusion furnaces

- Uneconomic energy and time consumption if heating the retorts are heated with gas torches, because excessive heating times of nearly 45 minutes are needed

Because of the poor results, the miners returned to burning amalgam in the open air.

Another distillation attempt was made in the mining area with a differently designed retort from MEDMIN, which promised to overcome some of the previous limitations, but the following deficiencies still remained:

- Absence of a rapid and economic heating source

- Uncertain sealing of the screw top of the retort.

\section{Proposal for mercury recovery with appropriate techniques}

After the rejection by the miners of the tested retort models, the Río Suratá Project looked for a solution to the low acceptance of new distillation retorts, and decided to offer an integrated system for the distillation of amalgams. A heating system needed to be designed that would fit the characteristics and dimensions of the retort. Experiments were started to identify adequate materials and designs for the two principal elements of a distillation system: heating unit and distillation retort.

\section{Heating unit}

The development of the heating unit involved the design of a heating furnace and the choice of heat source. The main heat source chosen was propane gas, which is generally preferred because it is readily available in the mining areas, and safe, clean and economical. Torches or burners were chosen as the heating device, with the alternative use of portable gasoline stoves in consideration of miners who live long distances from accessible roads.

As for the design and material of the furnaces, experiments were carried out on cylindrical designs resembling the tubular smelting furnaces of the ore treatment plants already used in the VetasCalifornia mining area. Investigations were carried out on the thermal behaviour of furnaces made of clay, carbon steel furnaces without covers, and carbon steel furnaces with an internal cover of refractory cement. The latter produced the best thermal results, and was the most stable. In the final design, the combustion chambers of the gas and gasoline furnaces have a capacity of $1530 \mathrm{~cm}^{3}$ (Figure 3).

For propane-gas-fired units, the torch manufactured by the Brasilian company Jackwal (Ref.No. 75.102.200) was selected 


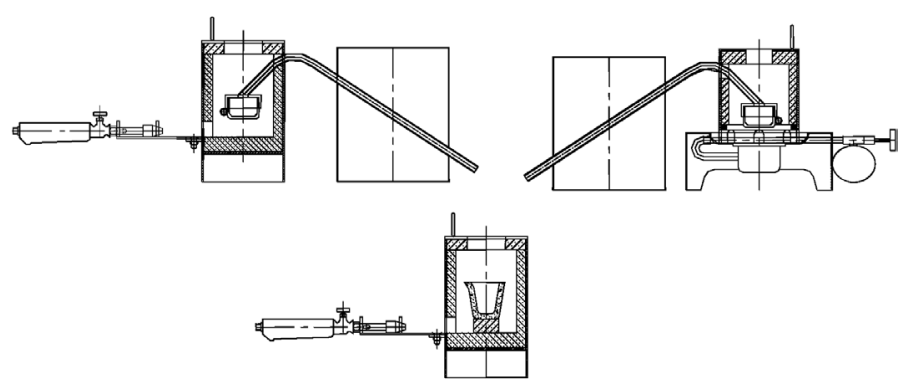

Figure 3 Diagram of the integrated distillation system for amalgams with gas and gasoline heating units and fusion systems for the smelting of free gold (from above left to below centre: gasoperated system, gasoline-operated system, and fusion system for free gold)

because it is safe and easy to operate, and moreover simple to repair since spare parts are readily available on the local market. The diameters of the gas and air injectors of the torch were modified from 0.2 to $0.8 \mathrm{~mm}$ for the gas nozzle and from 2 to $5 \mathrm{~mm}$ for the air nozzle, a change which resulted in a nominal gas consumption of $1200 \mathrm{~g} / \mathrm{h}$ (manufacturer's figures).

\section{Distillation retort}

After analysing the limitations of the known models, the retort was modified to operate with gas or gasoline heating units. To recover clean mercury for reuse in the barrels, stainless steel AISI 304 was used for those parts of the retort in contact with metallic mercury and its vapours (distillation vessel and condensation tube). For the refrigeration tank, galvanised sheet iron was employed due to its low cost and high resistance to corrosion.

The curvature of the condensation tube was designed to avoid the return of mercury into the retort vessel, and to make sure that all of the distilled mercury enters the condensation tube for maximum recovery. During heating, this section of the tube is subjected to similar temperatures as the retort vessel. To reduce the quantity of mercury sticking to the vessel walls, the slope of the water-cooled section of the condensation tube was increased compared to traditional retorts.

To accommodate the miners' wishes, two distillation vessels were incorporated in the system, with capacities of up to $200 \mathrm{~g}$ and $400 \mathrm{~g}$ amalgam respectively. The retort vessels have conical threads which permit autohermetic sealing. The refrigeration tank is cylindrical for increased handling stability, and has a capacity of 7.8 liters of water, which guarantees continuous cooling (Figure 3).

\section{System testing}

Distillation tests were run in the metallurgic laboratory of the Río Suratá Project, and in the municipalities of Vetas and California, using metallic mercury and amalgams, for which the mercury contents were determined. The system was also tested with amalgam samples provided by the miners, in which the mercury content could not be determined. The results are shown in Table 1 .

The table shows that the distillation of metallic mercury resulted in a recovery of $99 \%$, reflecting the air-tightness of the distillation vessel. Compared with gas-operated systems, the gasoline-run tests were more time consuming due to the natural air draught and the standard consumption of the stove, but recovery is still around $90 \%$.

Table 1 Results of distillation tests of mercury and amalgams (n.d. = not determined)

\begin{tabular}{c|c|c|c|c|c|c|c}
\hline Sample & $\begin{array}{c}\text { Weight } \\
(\mathbf{g})\end{array}$ & $\begin{array}{c}\text { Mercury } \\
(\mathbf{g})\end{array}$ & $\begin{array}{c}\text { Heating } \\
\text { unit }\end{array}$ & $\begin{array}{c}\text { Time } \\
(\mathbf{m i n})\end{array}$ & $\begin{array}{c}\text { Distilled } \\
\text { mercury } \\
(\mathbf{g})\end{array}$ & $\begin{array}{c}\text { Gold } \\
\text { sponge } \\
(\mathbf{g})\end{array}$ & $\begin{array}{c}\text { Mercury } \\
\text { recovery } \\
(\mathbf{\%})\end{array}$ \\
\hline Mercury & 50 & 50 & Gas & 8.3 & 49.76 & 0.0 & 99 \\
\hline Amalgam & 6 & 3.2 & Gasoline & 15 & 2.9 & 4.3 & 90 \\
\hline Amalgam & 4 & 1.8 & Gas & 9 & 1.6 & 2.2 & 89 \\
\hline Amalgam & 15.9 & 5.2 & Gas & 10 & 4.8 & 10.6 & 92 \\
\hline Amalgam & 69.8 & n.d. & Gas & 10 & 39.6 & 27.6 & $>94$ \\
\hline
\end{tabular}

* Amalgam sample provided by miner. Mercury recovery has been calculated from the difference in weight.
Distillation with gas is faster, and shows better recovery results (more than $92 \%$ ), which is mainly due to the higher thermal efficiency of the burner.

Low weight amalgam samples have lower mercury recovery rates than heavier samples. This shortfall between sampled and distilled mercury can be explained by mercury residues on the interior walls of the condensation tube and/or mercury retained by the gold sponge.

\section{System manufacturing and operating costs}

For the complete distillation of an amalgam sample, 10 minutes and $0.2 \mathrm{lbs}$ of propane gas are needed in the gas-operated heating unit. The gasoline-operated unit requires 20 minutes and $300 \mathrm{ml}$ of fuel. The condensation rate of mercury for gas-run operations is shown in Figure 4, which reveals that about $95 \%$ of a sample of metallic mercury deposited in the vessel of the retort is distilled and condensed in 8 minutes.

The time-versus-heating curve of the system shows that the temperature on the outside wall of the retort vessel reaches $600^{\circ} \mathrm{C}$ after 8 minutes (Figure 5). However, it is possible to achieve temperatures of more than $900^{\circ} \mathrm{C}$ by heating the amalgam sample with a gas injection torch in a graphite crucible of $500 \mathrm{~g}$ capacity for about 20 minutes, allowing the fusion of small quantities of free gold.

The cost of the integrated distillation system with a gasoperated heating unit is US\$90, and that of a system with a gasolinerun heating unit is US\$ 80 .

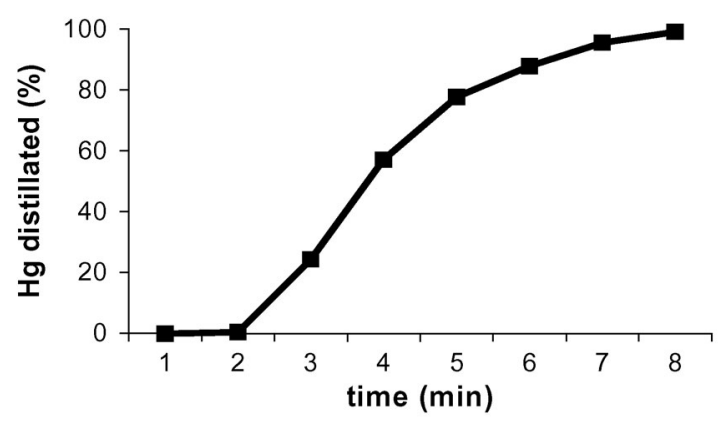

Figure 4 Mercury condensation rate.

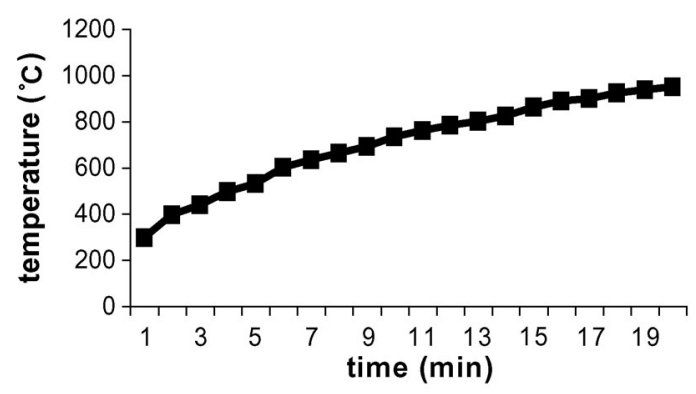

Figure 5 Heating curve.

\section{Introduction of the system in the mining district}

After evaluating the system in the laboratory and presenting the results to the mining municipalities, implementation of the distillation system in the project area was initiated using the following approach: - Information workshops and technical demonstrations. Together with local doctors with experience and knowledge of the mining world, informative workshops were organised for mining plant personnel and municipal schools and colleges. The aim of the medical workshops was to show the importance of preventing mercury fumes, providing information on contamination consequences and the negative effect the fumes have on health. At the end of each 
workshop, technical personnel of the Río Suratá Project carried out a practical demonstration of the distillation of amalgam samples from material supplied by miners, to show the efficiency of the integrated distillation system and how it was operated.

- Publications. Together with the doctors, leaflets were designed detailing the risks of mercury handling, and providing instructions on how to handle the retort. The leaflets are written in simple language to make sure that the message gets across.

After familiarising the public with the distillation system, the mining communities with the highest demand were provided with retorts, and all the miners were instructed on their use. One hundred distillation systems were distributed free of charge to all mineral processing plants in the communities and to individual mine operators.

\section{Conclusions}

The Vetas-California mining district is geologically part of the Santander Massif. The mineralisation of the Vetas-California mining district is mainly in the form of structurally controlled veins, frequently in association with hydrothermal alteration. The miners of the region use mercury and cyanide to extract the gold. The processing residues are discharged into nearby waterways, contaminating the waters of the Suratá river basin.

The "Reduction of Environmental Contamination by Small-Scale Mining in the Suratá River Basin" project (Río Suratá Project) began in 1997. For the safe and efficient distillation of amalgams with weights of 3 to $200 \mathrm{~g}$, an integrated distillation system was designed and manufactured with local materials and manpower. The system is easy to operate, durable and economical. It was tested and found to be successful, and proved to be an indispensable tool which improved the quality of life of the miners and reduced mercury contamination.

Although the immediate objective of the integrated distillation system is the elimination of contaminating mercury fumes during the heat treatment of amalgams, the system also has the attractive economic side-effect of significantly reducing the amount of mercury purchased by miners, due to the better quality of the recovered mercury, which can be reused in the amalgamation barrels.

The manufacturing and operating costs of the new distillation system are low, with the recovered mercury easily compensating for the fuel costs. In addition, the heating unit of the system may be used for the fusion of free gold and distilled amalgams, which, due to their poor quality and appearance, are either rejected by the gold buyers or only attract a low price.

In view of similar technical problems in other ore treatment operations involving small-scale gold mining, the Río Suratá Project is interested in the adoption of the new distillation system in other parts of Colombia, as well as in other countries. For this reason, the construction drawings of the new integrated distillation system may be obtained free of charge from the CDMB (Subdirección de Normalización y Calidad Ambiental, e-mail: hernando.guevara@cdmb.gov.co, with copy to Proyecto Río Suratá,prs1@cdmb.gov.co)

\section{References}

GTZ, Projekt-Consult and CORPONARIÑO, 1992, Mitigación de Emisiones de Mercurio en la Pequeña Minería Aurífera de Nariño / Colombia. Pasto (Colombia) and Königstein (Germany).

Heald, P., Foley, N.K. \& Hayba, D.O., 1987, Comparative anatomy of volcanic-hosted epithermal deposits: Acid-sulfate and adularia-sericite types: Economic Geology, 82:1-26.

Hedenquist, J.W., 1987, Mineralisation associated with volcanic-related hydrothermal systems in the Circum-Pacific Basin, in N.K. Horn (ed.), Transactions of 4th Circum Pacific Energy and Mineral Resources Conference, Singapore: American Association of Petroleum Geologists, 513-524

Herb, P., Hahn, L., Burgath, K.-P., Wittich, CH. \& Wolff, E., 2000, The mineralisation of Bucaramanga, Colombia-Implications to ore recovery. Proceedings of the Sixth International Congress on Applied Mineralogy ICAM 2000, Göttingen, Germany, 17-19. July 2000: Applied Mineralogy, Vol. 1: 345-348, Rotterdam
INGEOMINAS, 1999, Geología del Departamento del SANTANDER (compilado por: Royero Gutiérrez, J.M. y Vargas Higuera, R.), 1:300 000. Bogotá.

Leon, L.A., García, H., y Zambrano, J., 1995, Paragénesis y evaluación de los yacimientos de oro del distrito minero de Vetas (S), Universidad Industrial de Santander, Dirección de Investigaciones, 99pp.

Mendoza, H. y Jaramillo, L., 1979, Geología y geoquímica del área de California, Santander: Bol. Geol. Ingeominas, Bogotá, Vol XXII, No 2: 52pp.

Ward, D.E., Goldsmith, R., Cruz, J. y Restrepo, H., 1973, Geología de los cuadrángulos H-12 Bucaramanga y H-13 Pamplona, Departamento de Santander: Bol. Geol. Ingeominas, Bogotá, Vol XXI, No 1-3: 132pp.

Wotruba, H., Hruschka, F., Hentschel, T., Priester, M., 1998, Manejo Ambiental en la Pequeña Minería. MEDMIN-COSUDE. La Paz.

Erwin Wolff Carreño received his master's degree in Geology at Industrial University of Santander in 1991. He finished a specialisation in Environmental Engineering in 2000. Since 1997 he is with Corporación Autónoma Regional Para la Defensa de la Meseta de Bucaramanga$C D M B$ and is in charge of the technical coordination of the Río Suratá Project.

Juan Manuel Pinzón Angel received his master's degree in Metallurgical Engineering from Industrial University of Santander in 1996. In 2000, he finished a specialization in Environmental Engineering. Since 1997 he is with Corporación Autónoma Regional Para la Defensa de la Meseta de Bucaramanga-CDMB and is in charge of the metallurgical team within the Río Surata Project.

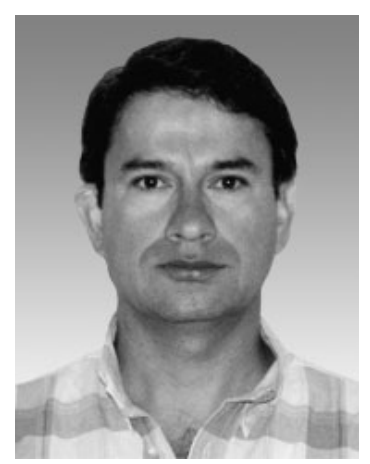

Rodolfo Contreras Moreno received his master's degree in metallurgical engineering from Industrial University of Santander in 1998. Born in the mining village of Vetas, he is familiar with all aspects associated to small-scale gold mining. From 1999 to 2002, he worked with the Rio Surata Project and since then he is the director of

Reina de Oro Goldmine in Vetas.
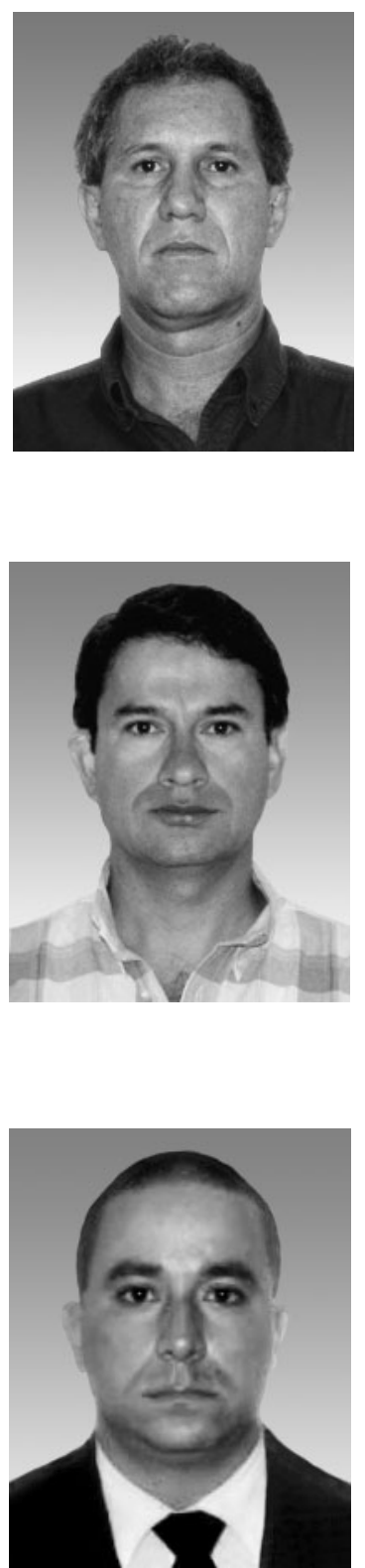